Łukasz Kołtuniak

Jagiellonian University in Kraków (Poland)

\title{
Not Only the War. The Ideology of Polish Underground State
}

Book review: Jerzy Juchnowski \& Jan Ryszard Sielezin, The concept of state and nation in Polish political thought in the period of war and occupation (1939-1945). Wydawnictwo Adam Marszałek Torun 2016 (pp. 295).

ISBN: 978-83-8019-487-8.

The Polish Underground State during the Second World War has been the topic of different studies. However, the majority of them focused on the conspiracy and fighting for the survival of the nation. For that reason, Jerzy Juchnowski and Jan Ryszard Sielezin try to present the less analysed ideologies of the most prominent political movements, in the time of the Polish underground state. The doctrines are very interesting because in the Polish historical discourse there was not a complex book about the ideologies of the Polish underground state. The former books focused on military fighting or the ideologies of separate movements, for example, the ideologies of the nationalist movement.

According to the authors, such an analysis covers the gap in the research concerning the underground state. The book The concept of state and nation in Polish political thought in the period of war and occupation (1939-1945) is divided into four chapters. In the first chapter the authors present the methodological approaches of their book. In their methodological approach, the amount of the ideas and programme in the occupied Poland was so high that it was necessary to choose only some of the programmes that the party proposed in that period. The authors propose the criteria of relevance of this programme. First of all, they chose the biggest political movements including the socialist and communist movement, the nationalist, peasant movement in the occupied state and obviously the ideologies of the exile governments. The authors propose only the analysis of the biggest political parties within the movements. Such criteria seem to be justified. The authors show 
that due to an overwhelming amount of political parties and blocs in the occupied countries, it was impossible to analyse all of them.

In the chapter two to four the authors analyse the idea of choosing movements in the light of the political situation in the world policy and German policy on the occupied territory. The line of thinking in the book is about popularising a Polish independent fight abroad. For that reason it seems to be fully justified that the authors memorise Polish history of the Second World War even if it seems to be too general or even unnecessary from the point of view of Polish readers.

The programmes of the biggest movements are shown in a neutral way. The authors include only two general assumptions. Firstly, there were none, or rather almost no movements that proposed going back to the vision of Poland before 1939. Secondly, the most important difference in the underground state was concerned with the distinction between the pro-independence majority and the communist movement.

The authors describe the idea of the main political forces in a satisfied and complete way. The Authors use very original and specific sources. This book could popularise the study of the underground state. This discourse can be very interesting. As the authors suggest this newspaper not only described the war with Germany but also asked how we want to build the future of Poland?. In addition it is fully justified that the authors have selected materials according to the criteria of relevance. According to the authors, the distinction of the programmes in the occupied state was so high that it is impossible to present the general conclusion connected with these ideas. However, it is visible that all these parties were in favour of social reforms, education reforms and the general modernisation of the society. This tendency in Poland was similar to the progressive movements in the Western occupied (or not occupied as Britain) movement (Wojcik, 2017, Bartoszewski, 1980). Such a tendency during the post-war time in the Western Europe has resulted in the social reforms called "welfare state". Could the situation in Poland be similar? But the question do the programmes of the underground's pro-independence movement suggest future social revolution in Poland? is fully justified. From the other side the basic ideas of the nationalist movement seem to be similar to something like corporationism. The researchers suggest that in the case of victory for the nationalist movement Poland would probably evolve into the state of combined social reform and conservative ideology (Engelgard 2015; Leder 2014). In fact, it is very difficult to find common elements within such a different declaration. But the attempt to foresee the evolving future of Poland in case of a victorious non-communist power in the light of the after-war European tendency could be a very strong element for their future analyses.

In the last chapter, the authors suggest that the future research should focus on the political thought of the Polish underground state. In my opinion, their book is a very good beginning. Personally I think that in the light of the contemporary popularity of the Polish underground state, it could be more than justified to analyse not only the elements of fighting, but also the attempts to rebuild the Polish state in a better form. 


\section{References:}

Bartoszewski, W. (1980). Tajna prasa w okresie okupacji 1939-1945 i jej rola w społeczeństwie 1939-1945. Warszawa: Wydawnictwo S.N.

Engelgard, J. (2015). Bolesław Piasecki 1939-1956.Warszawa: Wydawnictwo Myśl Polska.

Juchnowski, J., \& Sielezin, J.R. (2016). The concept of state and nation in Polish political thought in the period of war and occupation (1939-1945). Toruń: Wydawnictwo Adam Marszałek.

Leder, A. (2014). Prześniona rewolucja; ćwiczenie z logiki historycznej. Warszawa: Wydawnictwo Krytyki Politycznej.

Wójcik, B. (2017). Rzeczpospolita której nie było. Kraków: Klub Jagielloński.

\section{Author}

\section{Mr Lukasz Koltuniak}

Jagiellonian University, Faculty of Law

Contact details: ul. Gołębia 24, 31-007 Kraków, Poland

e-mail:lukasz_koltuniak@poczta.onet.pl 